\title{
Analysis on the Obstacles for China to Become a Financial Superpower
}

\author{
Xiaoya Zhang \\ Economics, Simon Fraser University, Burnaby, BC, Canada
}

\begin{abstract}
This study draws the following conclusion through the analysis method of literature review. At present, the most important factor that hinders China becoming a financial superpower is the increase of the control of capital outflow, what will weaken the trust between the capital outflow country and foreign investors, and destroy the relationship established by the country on the international platform. In addition, China's aging population increases the huge debt increase is also the reason why it is difficult to becomes a financial superpower. This paper puts forward some remedial measures for these challenges. One way is one belt and one road initiative to reduce state control of capital and regulate the monetary system. These actions will help China compete with other developed countries as a financial superpower. There are three reasons for this conclusion. Firstly, when compared to other global superpowers like the United States and the United Kingdom, China is still lagging behind in terms of its GDP. Moreover, the state has monopolized a lot of financial decisions in the country such as capital outflows and therefore curbing economic growth. Thirdly, the State control has spilled over to the foreign exchange market and the country has been known to limit its currency lending capacity. Therefore, the internalization of their currency has halted.
\end{abstract}

\section{INTRODUCTION}

The research topic of this paper is the obstacles that hinder China from becoming a financial superpower, which is based on the research background that China is a middle income country that always has the aspiration to become a global financial superpower and to compete at the same level with other financial superpowers such as the United States, United Kingdom and Germany [8]. The state has announced that China hopes to become the global financial superpower by the middle of this century. However, this goal currently is unattainable [8].

The research method of this paper is literature review. Therefore, the conclusion is drawn by collecting relevant literature and data, and analyzing them.

The significance of this research topic is extraordinary. As the largest developing country in the world, every small change in China may exert crucial influences on the world's finance. Studying the obstacles in its financial development can help people understand the future trend of China as an economy entity. At present, the most important factor hindering China from becoming a financial superpower is to increase the control of capital outflow, what will weaken the trust between the capital outflow country and foreign investors, and destroy the relationship established by the country on the international platform. In addition, China's aging population has lifted the huge increase of debt, which also hinders China's development. One belt and one road, and foreign investment are also put forward by understanding these situation.
A superpower is a country that has great military power, effective global diplomacy and influence. Although China has been experiencing economic growth in the last few decades, the costs the country incurs right now cannot be compared to the costs that the country will bear as a superpower in maintaining the strong military and influence. Furthermore, the country is currently dealing with the growing aging demographic that needs a heavy investment in social security. Nevertheless, the country is still too poor to bear the costs [8].

\section{REASONS}

\subsection{Compareing to financial superpowers}

If the US economic growth rate continues to rise at the same rate until the year 2049 and the estimated Chinese annual growth rate is $6 \%$. This growth rate cannot match the US economic growth rate. Furthermore, the country continues to struggle in its poverty due to the huge debt. The country's enormous debt can no longer be ignored. In the first few months of 2019, the country's debt stood at $300 \%$ of its GDP [10]. The reason for this immense debt is the heavy borrowing the country has done to drive growth on the global platform. Furthermore, the trade wars with the United States have only been damaging the debt levels in the country [10]. Due to the trade frictions between China and the United States, which will lead to the deterioration of the world economic environment, China may have to relax 
monetary policy in order to stabilize economic growth, which will contribute to China's debt accumulation, increase the medium-term financial risks, and hinder the long-term healthy development of the economy. Most critics state that the trade wars the country experienced will not have as significant adverse impact on the economy as that of the growing debt [7]. The reason is that the Chinese government can issue government bonds to obtain certain capital flow. The credibility of China's government is relatively high, so issuing bonds is also a way to help the government regain funds. With the capital flow, the government can better put the capital into the corresponding production and development to alleviate the impact of the Sino US trade war on China.

China has experienced a slow decline in economic growth since 2007. Apart from the increasing debt, the country is experiencing declines in the working population and increase in the ageing population due to one-child policy the country implemented in 1979 that has affected the population demographic. which includes a high number of old individuals [1]. By the year 2030 the working population is estimated to be at 25 million individuals.

Therefore, this drastic decline will have an adverse effect on the levels of productivity and consequently the country's economic growth [1]. China's future population projection is shown in the graph below [3].

Furthermore, the mismanagement of the country's resources and exhaustion of available technology that is important for expansion shows how poor China is compared to the developed countries[1]. The excessive government control in the financial sector produces many inconsistencies for investors, thus discrediting the argument that China will achieve financial superpower status in the near future [5]. Due to the different degree of China's population and economic development, the standardized management of local financial institutions is an important part of the development process of financial institutions, including the government's standardized management of the work of financial institutions, as well as the internal control of financial institutions. However, in the government control, many local governments adopt the traditional planned economy system to manage the work of local financial institutions when they manage the financial industry, which makes the business management efficiency of local financial institutions low, and even leads to the phenomenon of backward economic development of local financial institutions. In addition, in the actual work of local financial institutions, the business managers are still relatively backward in the management of financial business. Furthermore, the standard system of performance management is not perfect, and the development of local financial institutions is not well understood. Hence, the business management level of local financial institutions is not high. It can be seen from this that China is still in the stage of financial development, and the government has no way to completely liberalize finance. Taking the case of Greece into account, we see how this duality is a problem if the country ever gets into a financial crisis. Since the creditors are State owned financial institutions, during a crisis, debt or losses were transferred from one government branch to another [7]. Greece's financial institutions were also state-owned and therefore when the country had high amounts of debts from the bail-outs that the government made and the transfer of liability from one section of the state to the other.

\subsection{State's control over capital outflows}

The country has continued to hold on to the reins of financial power afraid other economic interests would rise that would affect the State's political power [8]. Therefore, the government has continued to implement policies that control the play in the market. The country has a contradictory dual role of or a regulator and that of an investor [8]. Because the country's control on capital outflows will negatively affect the country's strive for global financial dominance and its goal on establishing an international currency [14]. Therefor, curbing capital outflows means that the country controls how much local companies can remit outside the country. Financial superpowers like the United States have established their currencies as global currencies. However, these regulations by the China government inhibit the Yuan from being a global currency since their currency is weakening. The international market distrusts market regulation. Therefore, foreign investors are less likely to want to participate in that market. The country continues to issue stricter rules on overseas investors despite loosening grip in their Shenzhen and Hong Kong stock markets. This regulation affects the competitiveness of these markets on the global level. This is because the local companies are hindered from accessing cutting edge technology to improve their innovativeness. The Chinese Central government continues to remain vague on policies concerning the currency depreciation. This vagueness hurts the economy because foreign investors like to have adequate information before making long-term foreign market investments [14].

Furthermore, capital outflow control will work only in the short-term to help the exchange rate remain stable but in the long-run this strategy harms the economic growth [14]. For countries with low productivity such as China, due to the lack of capacity to produce products that meet the needs of the international market, the capacity of self generated capital is insufficient, and a large number of foreign investment is needed to meet the needs of national economic scale expansion. In this case, the outflow of capital will inevitably damage the economy. In order to control capital outflow, the Chinese government has taken some measures. These measures are aimed at the short-term speculative capital flow and have no impact on the foreign-funded enterprises that operate legally and remit income legally. However, foreign investors need to see the capital control followed by market reforms in order to gain trust to invest in that economy. 


\subsection{China's loans to other countries}

China's lending to other countries in secrecy and raised a lot of suspicion regarding the country's long-term objectives on their massive lending especially to African countries [13]. The massive lending has aroused distrust because of the lack of transparency and the fact that the loans are lent in the borrowing countries' currencies. The lack of transparency has affected foreign investment in these countries and subsequently affecting China's influence on the global platform. China's title as an international creditor has made other countries feel that the country is lending more than is disclosed and affecting debt sustainability in these developing countries [13]. These countries are becoming suspicious of China's motives because the debt is affecting their foreign direct investment and therefore their economic growth. Furthermore, the lending is contributing to the country's growing debt crisis.

\subsection{The internationalization of China's currency}

\begin{tabular}{|c|c|c|c|c|}
\hline \multirow{2}{*}{ Country/Economy $\vDash$} & \multicolumn{2}{|c|}{$\begin{array}{l}\text { GDP (Nominal) } \\
\text { (mitilions of \$) }\end{array}$} & \multicolumn{2}{|c|}{ Rank (Nominal) } \\
\hline & $2017 \leqslant$ & $2018 \neq$ & $2018^{A}$ & Change $A$ \\
\hline United States & $19,485,400$ & $20,544,300$ & 1 & 0 \\
\hline China & $12,143,500$ & $13,608,200$ & 2 & 0 \\
\hline Japan & $4,859,950$ & $4,971,320$ & 3 & 0 \\
\hline Germany & $3,656,750$ & $3,947,620$ & 4 & 0 \\
\hline United Kingdom & $2,666,230$ & $2,855,300$ & 5 & 0 \\
\hline France & $2,586,290$ & $2,777,540$ & 6 & 1 \\
\hline India & $2,652,240$ & $2,718,730$ & 7 & -1 \\
\hline Italy & $1,956,960$ & $2,083,860$ & 8 & 1 \\
\hline Brazil & $2,053,590$ & $1,868,630$ & 9 & -1 \\
\hline Canada & $1,646,870$ & $1,713,340$ & 10 & 0 \\
\hline
\end{tabular}

Figure 1. 2018 World GDP ranking

As can be seen from the figure 1, China's GDP is as the second largest economy in the world after the United States. A country's strong economic foundation is an important support and guarantee for its currency to obtain corresponding status in the international reserve currency system. As the largest developing country in the world and the second largest economy entity in the world, China has the economic scale necessary for the establishment of a deep and liquid financial market; meanwhile, the huge foreign trade and foreign capital inflow provide the establishment of a RMB based financial trading market.with good endogenous conditions. However, a little over four years ago, the Chinese currency placed fourth on the global platform as the most traded currency in the world. Besides, the performance of the renminbi droped the last few years relative to other global currencies [9]. This is due to the slowdown in the use of cross-border revenue and expenditure of RMB under the expectation of periodic depreciation of RMB exchange rate. Due to the change of holding motivation of RMB of overseas investors and main forms of international trade and economic cooperation of domestic enterprises, the main mode of RMB exported to the world is gradually changing to international financial market and foreign direct investment channel, and the weight of financial transaction settlement in the dynamic structure of RMB internationalization is increased. With the completion of the switching of driving factors, the process of RMB internationalization gradually slows down. Foreign exchange market trade with yuan made up $30 \%$ of Chinese trade in 2014, but the Chinese currency dominated trade has made up half of the total Chinese trade. The current trends in the international financial market shows the anti-internalization of the Chinese currency.

China hoped to use their oil trading platform to push exporters to use the renminbi to establish their prices [12]. However, this strategy has failed to take off because most oil exporters set their prices using the US dollar. Foreign investors are less likely to have an affinity for currencies other than the dollar because of the risk attached. One reason that the Chinese currency cannot compare to internalized level of the US dollar is that the US economy is massive and its level of trading. Furthermore, the US financial markets have more accountability and transparency, when compared to Chinese financial market that is riddled with suspicion and distrust. Since the US market can be trusted and is predictable it is easy to see why many investors opt for the dollar over the yuan[11]. Furthermore, the yuan currency is unpredictable and cannot be used in global oil trading and hence would not be used as the global currency.

\section{SUGGESTIONS}

\subsection{Relax China's capital control}

As a large economy entity, China can absorb the inflow of capital without great impact. People's expectation for RMB is appreciation. With this understanding, people want to change any currency into RMB. The patience of hot money is extremely limited. If the country cannot make money quickly, it will flow out quickly. Meanwhile, hot money is reluctant to invest in infrastructure. In terms of nature, the nature of hot money is to pursue fast returns. If you don't see fast returns, you will change your nature and become "cold money". To enhance the internalization of the currency, China has to relax capital controls. When foreign investors have more freedom to save and invest using the Chinese currency, then the currency will be preferred more on an international level [12]. Relaxing controls on capital outflows ensures that the country has large stocks of foreign investment in their country. This shows that foreign investors are willing to participate in the exchange market. Whereas, it is unfortunate that the Chinese government is reluctant to remove controls because they want to maintain control on the country's exchange rate without international market interference [12]. 


\subsection{Standardize system such as the China International Payment System}

In the last few years, China has created ambitious goals that will lead the country to establish a standardized system. In order for this system to work, the country has to step away from State control and the "China only" policies that separate the country from the global markets [15]. The country has to take into consideration international competition. Meanwile, the country not only needs to research on international standards but also needs to continuously engage and participate in these markets. As the result, China needs to establish a comprehensive standardized system for technical regulations in the country. Without this comprehensive framework, the country cannot implement solutions to ensure product safety and cannot ensure that implemented financial market reforms will be effective. Therefor,a new better form of standardization will enable the country to fully and effectively participate in trade negotiations on the international platform. However, the first step is loosening the political grip the government has on the market.

\section{CONCLUSION}

There have been many reports about the rise of China to financial superpower status since its penetration to the international market and expansion of manufacturing and industrialization that have seen the country rise from poverty to a middle income country. However, this status will not be easily achieved in the near future.

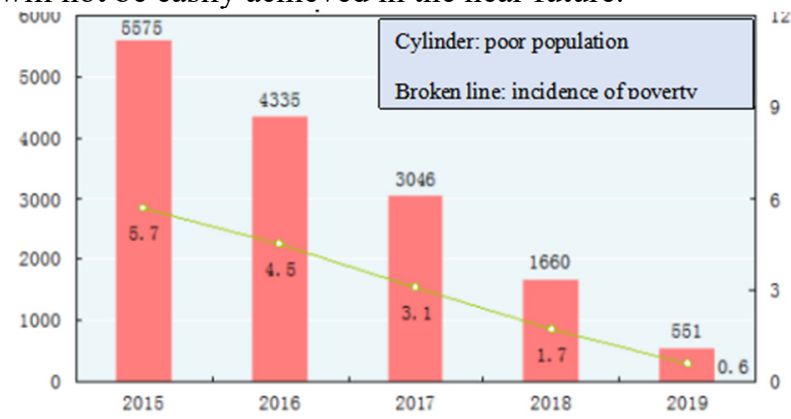

Figure 2. 2015-2019 China's poverty population and poverty rate

The red column shows the poor population, and the green curve shows the incidence of poverty. Although the number of poor people in China is decreasing, the gap between the rich and the poor is also very large. The country continues to struggle with poverty levels due to the increasing number of the ageing population, huge debt, and declining economic growth. Moreover, the government of China under president Xi has continued to increase the control on capital outflows, thus weakening the trust the country has with foreign investors and undermining the relationships the country has built on the international platform. The foreign exchange market and the country's currency have suffered as a consequence. As a result, the currency cannot stand to compete with other mighty currencies like the US dollar. Therefore, it is imperative that
China looks outside itself for solutions in order to improve its competitiveness and elevate its status. The government needs to allow for a free market with limited regulations and to improve its relationships on the international market. The financial institutions and systems need to be reformed so that they operate competitively, thus attracting foreign investment so that China can implement to achieve superpower financial status.

\section{ACKNOWLEDGEMENT}

First and foremost, I would like to show my deepest gratitude to my teachers and professors in my university, who have provided me with valuable guidance in every stage of the writing of this thesis. Further, I would like to thank all my friends and roommates for their encouragement and support. Without all their enlightening instruction and impressive kindness, I could not have completed my thesis.

\section{REFERENCES}

1. R.Avent. China is not the economic superpower people think. That's why it's important to wait it out Retrieved from The Washington Post: https://www.washingtonpost.com/business/economy /china-is-not-the-economic-superpower-people-thin k-thats-why-its-important-to-wait-itout/2018/12/21/cf9999bc-03b1-11e9-b6a9-0aa5c2fc c9e4_story.html. Dec. 22, 2018. Accessed on 1 Apr, 2020

2. A. Chatzky, J. McBrid. China's Massive Belt and Road Initiative. Retrieved from Council on

Foreign Relations:

https://www.cfr.org/backgrounder/chinas-massive-b elt-and-road-initiative. Jan. 28, 2020. Accessed on 1 Apr, 2020

3. China Power Team. Does China have an aging problem? Retrieved from China Power: https://chinapower.csis.org/aging-problem/. Agu. 11, 2017. Accessed on 1 Apr, 2020

4. Y. Cao. The Prospect of Internationalizing the RMB. Strategies for Internationalizing the Renminbi, 2018, pp.191-204

5. S. Hsu. Why China Won't Replace The U.S. As The World's Superpower. Retrieved from Forbes: https://www.forbes.com/sites/sarahsu/2017/02/02/w hy-china-wont-replace-the-u-s-as-the-worlds-superp ower/\#1c774b06234d. Feb, 2, 2017. Accessed on 1 Apr, 2020

6. W. Li. Optimization of Economic Structure and China's Growth Potential, China's Macroeconomic Outlook. 2016, pp.35-42

7. P. Mourdoukoutas. Debt, Not Trade War, Is China's Biggest Problem. Retrieved from Forbes: https://www.forbes.com/sites/panosmourdoukoutas/ 2018/11/24/debt-not-trade-war-is-chinas-biggest-pro blem/\#6c4cc95e4c4d. Nov. 24, 2018. Accessed on 1 Apr, 2020 
8. C. Parton. Today's China will never be a superpower. Retrieved from Financial Times: https://www.ft.com/content/233b101e-7d51-11e9-81 d2- f785092ab560. May 27, 2019. Accessed on 1 Apr, 2020

9. H. Sender. China pauses in push to internationalise its currency. Retrieved from Financial Times: https:/www.ft.com/content/14279cc6-55e4-11e9-91 f9- b6515a54c5b1. Apr. 4, 2019. Accessed on 1 Apr, 2020

10. S. Sharma. China's enormous debt 'no longer can be ignored,' analyst says. Retrieved from CNBC: https://www.cnbc.com/2019/08/23/chinas-debtlevels-amid-its-slowing-economy.html. Aug. 23, 2019. Accessed on 1 Apr, 2020

11. C. Smith. China's currency will not replace the US dollar. Financial Times, 2018

12. B. Stei, B. D. Rocca. China's Currency Internationalization Is Failing; Oil Futures Won't Rescue It. Retrieved from Council on Foreign Relations:

https://www.cfr.org/blog/chinas-currency-internatio nalization-failing-oil-futures- wont-rescue-it. Apr. 18, 2018. Accessed on 1 Apr, 2020

13. W. Tan. China's loans to other countries are causing 'hidden' debt. That may be a problem. Retrieved from CNBC: https://www.cnbc.com/2019/06/12/chinas-loans-cau sing-hidden-debt-risk-to-economies.html. Jun. 12, 2019. Accessed on 1 Apr, 2020

14. V. Zhou, S. Leng. (2016, December 5). China's capital controls 'can harm currency, global ambitions'. Retrieved from South China Morrning Post:

https://www.scmp.com/news/china/economy/article/ 2051251/chinas-capital-controls-can-harm-currencyglobal-ambitions $\backslash$. Dec. 5, 2016. Accessed on 1 Apr, 2020

15. K. Ziegler. China's Global Ambition to Standardization - Impact on Trading Partners. 2016, pp. 1-15. 